Maciej Trojnar

\title{
Zależność między narodowością a religijnością na przykładzie archidiecezji wileńskiej
}

\section{The relationship between nationality and religiosity on the example of the Archdiocese of Vilnius}

\begin{abstract}
The purpose of the study presented in this paper was to compare objectively measurable indices of religiosity (dominicantes and communicantes) for the national groups living in the same area. The area of the Archdiocese of Vilnius inhabited by the Polish and Lithuanian communities was analysed. The study attempted to determine the number of inhabitants of a given nationality within the boundaries of individual parishes, and then, owing to field measurements, to calculate the indices for both these national groups. Factors that could have an effect on the misinterpretation of the results were also discussed.

The results obtained in the case of the dominicantes index were two times higher, and for the communicantes index three times higher for the Polish community. This seems to confirm the hypothesis of the relationship between national identity and the degree of piety, which is verified by the turnout at the mandatory Sunday liturgy. However, the number of operational units under the study was too small to be able to draw more general conclusions about the entire communities living in the study area. In the Archdiocese of Vilnius, there are 30 parishes with at least one Holy Mass on Sundays in both languages. Five parishes of various ethnic compositions were selected for the survey: the parishes of Landvars and Trakai with the dominant Lithuanian population, the parish of Rudziszki, where there is a similar number of representatives of the two nationalities, and the parishes of Podbrzezie and Kowalczuki dominated by the Polish population.
\end{abstract}

Keywords: Lithuania, Poles in Lithuania, religiosity, Archdiocese of Vilnius 


\section{Wprowadzenie}

Religia, podobnie jak język, kultura, terytorium czy więzy krwi, stanowi znaczący czynnik kształtowania tożsamości narodowej (Żelazny 2006). Szczególnie na pograniczach pozostaje ważną płaszczyzną kontaktów i etnicznych odrębności. Babiński (1997) wyróżnia trzy podstawowe typy zróżnicowań społeczności narodowych na pograniczu: 1) społeczności narodowe są homogeniczne, ale wyznają różne religie; 2) różne społeczności narodowe wyznają tę samą religię; 3) społeczności narodowe są heterogeniczne religijnie, z tym że niektóre religie mogą być wspólne, a inne odmienne.

W wielu sytuacjach tożsamość religijna i narodowa są ze sobą ściśle związane (typ 1), a nawet wzajemnie utożsamiane, natomiast $w$ innych przypadkach takie powiązanie nie występuje (typ 3). O ile jednak związki między przynależnością do grup narodowych i religijnych są dobrze znane i opisane w literaturze, o tyle trudno znaleźć prace, które badałyby religijność (rozumianą jako zaangażowanie religijne) w zależności od przynależności narodowej. Wspólny obszar oraz wyznanie sprawiają, że do tego typu badań szczególnie predestynowane są pogranicza typu 2. Obszar archidiecezji wileńskiej ze względu na obecność zarówno społeczności litewskiej, jak i polskiej (Eberhardt 1998) niewątpliwie należy przyporządkować do tego typu. Niniejszy artykuł prezentujący wyniki badań przeprowadzonych na Litwie ma stanowić uzupełnienie wspomnianej wcześniej luki.

\section{Struktura religijna na Litwie}

Spis powszechny przeprowadzony w $2011 \mathrm{r}$. podaje, że na Litwie funkcjonuje 59 wspólnot religijnych (dla porównania w 2001 r. było ich 28), wśród których 11 ma ponad 1000 wiernych (Vaitekūnienè 2013). Największą wspólnotą jest Kościół Rzymskokatolicki, który liczy 2350478 wiernych, tj. 77,23\% ogółu ludności. W porównaniu ze spisem z 2001 r., kiedy wartości te wyniosły odpowiednio 2752447 osób i 79\%, liczba katolików spadła o blisko 2 punkty procentowe. Drugą pod względem liczebności wspólnotą są prawosławni: 125 189, tj. 4,11\% (w 2001 było to: 141821 wiernych, tj. 4,07\%), trzecią starowiercy 23330 osób, tj. 0,77\% (w 2001 było to: 25189 wiernych, tj. 0,78\%), kolejne dwie pozycje zajmują ewangelicy augsburscy, tj. luteranie oraz ewangelicy reformowani, którzy mieli w 2011 odpowiednio 18 376, tj. 0,6\% i 6 731, tj. 0,22\% 
wiernych (w 2001 było to: 19 637, tj. 0,56\% i 7 082, tj. 0,22\%). Warto zwrócić uwagę na religie bałtyckie, do których przynależność deklarowało 1270 osób w 2001 r., natomiast dekade później już ponad czterokrotnie więcej - 5118 osób, tj. 0,17\% ogółu społeczeństwa. Pozycje siódmą i ósmą wśród związków religijnych zajmowali Świadkowie Jehowy oraz muzułmanie. Kolejne wspólnoty liczyły już znacznie mniej członków. Liczba osób nienależących do żadnej wspólnoty lub odmawiających udzielenia odpowiedzi na pytanie o wyznanie (liczone wspólnie) wzrosła z 14,85\% w 2001 r. do 16,28\% w 2011 r. W dalszej części artykułu obie te grupy łącznie będą określane mianem niewierzący, choć należy mieć na uwadze, że odmowa udzielenia odpowiedzi wcale nie musi oznaczać faktycznego braku przynależności do wspólnoty religijnej.

W wartościach bezwzględnych liczba wiernych spadła we wszystkich ośmiu największych wspólnotach (z wyjątkiem wspomnianych religii bałtyckich). Wynika to ze spadku ogólnej liczby ludności na Litwie (z 3483972 osób w 2001 r. do 3043429 osób w 2011 r., tj. o 12,64\% w ciągu dekady), co spowodowane było głównie intensywną emigracją ekonomiczną do Europy Zachodniej. W wartościach względnych wśród sześciu najliczniejszych wspólnot jedynie Kościół rzymskokatolicki odnotował spadek liczby wiernych, natomiast wszystkie pozostałe (pomijając niewielki spadek u staroobrzędowców) odnotowały względny wzrost wiernych.

Struktura wyznaniowa poszczególnych grup narodowych jest bardzo zróżnicowana. Największy odsetek niewierzących rejestruje się wśród społeczności żydowskiej (55,2\%), a następnie wśród Tatarów (32,2\%), Rosjan (23,7\%), i Litwinów $(15,2 \%)$. W grupie Polaków ta kategoria stanowi 10,2\%. Uwzględniając tylko wierzących katolicyzm jest wyznaniem dominującym wśród Polaków (98,6\%), Litwinów (katolicy obrządku rzymskiego stanowią 97,7\%) i Białorusinów (59\%). Bardziej zróżnicowana struktura występuje u Rosjan, prawosławni stanowią $67,6 \%$, a katolicy obrządku rzymskiego $(15,6 \%)$ nieznacznie przewyższają liczbę staroobrzędowców (15,5\%). Wśród Białorusinów drugim największym wyznaniem jest prawosławie $(38,4 \%)$. W przypadku wierzących Ukraińców najliczniejszą grupa są prawosławni $(77,2 \%$,$) katolicy obrządku rzymskiego to 17,8 \%$ społeczności, a katolicy obrządku greckiego 1,1\%. Z judaizmem utożsamia się 75,8\% religijnych Żydów, pozostali są związani z prawosławiem (12\%), katolicyzmem (9,9\%, obrządek rzymski) lub są to starowiercy (2,3\%). Wśród wierzących Tatarów największe grupy stanowią: muzułmanie $76,1 \%$, katolicy $11,5 \%$ i prawosławni $9 \%$. Warto zauważyć, że wśród Tatarów są również wyznawcy karaimizmu, stanowiący 1,3\% ogółu społeczności tatarskiej. Odsetek wyznawców karaimizmu w siedmiu 
pozostałych, najliczniejszych grupach narodowych, osiąga niewielką wartość maksymalnie 0,04\% ogółu (dokładnie wskaźniki są niemożliwe do wyliczenia ze względu na ograniczenia danych stosowane przez Litewski Departament Statystyki). Struktura wyznaniowa Karaimów ze względu na wyżej wymienione ograniczenia jest niemożliwa do obliczenia, jednak można przypuszczać, że większość wierzących Karaimów wyznaje karaimizm.

\section{Metody badań}

\subsection{Omówienie zastosowanych wskaźników}

Zbadanie zależności między narodowością a religijnością wymagało porównania zaangażowania religijnego dwóch grup narodowych tego samego wyznania, zamieszkujących wspólne terytorium. W przypadku Litwy, zarówno duża liczebność, jak i bardzo wysoki odsetek przynależności do Kościoła Rzymskokatolickiego zadecydowały o objęciu badaniem społeczności polskiej i litewskiej. Religijność jest zjawiskiem wielowymiarowym i różnorodnym, jednak w przypadku krajów katolickich może być łatwo sparametryzowana poprzez wskaźniki dominicantes oraz communicantes. Takie podejście badawcze wpisuje się we współczesny nurt socjologii religii, która korzystając z metod badań empirycznych stosuje wskaźniki ilościowe przy analizie przejawów życia religijnego (Ciupak 1982).

Wskaźnik dominicantes określa odsetek uczestniczących w niedzielnej mszy świętej w stosunku do ogółu wiernych, natomiast communicantes odsetek przystępujących do komunii świętej w stosunku do ogółu wiernych. Wskaźniki są uzyskiwane w drodze pomiaru statystycznego, a nie badania socjologicznego (www 1). Wyniki uzyskuje się na podstawie obserwacji (liczenia) wszystkich wiernych, którzy są obecni na niedzielnej mszy świętej (dominicantes) oraz przyjmujących komunię świętą (communicantes). Wskaźniki są zatem oparte na badaniu całej populacji obecnej na niedzielnej mszy, a nie subiektywnych odpowiedziach losowych respondentów. Zaletą tej procedury badawczej jest obiektywność danych, ponieważ zamiast pytać, czy respondent bierze udział w liturgii, stwierdzamy jego rzeczywiste zachowanie niemożliwe do ustalenia w badaniu ankietowym. Wskaźniki te dostarczają zatem obiektywnych wyników możliwych do dalszych interpretacji i analiz.

Istotnym zagadnieniem jest ustalenie liczby osób zobowiązanych do udziału we mszy św. Za zobowiązanych uznaje się tylko katolików (tj. osoby ochrzczone) mieszkających na terenie danej parafii. Przyjmuje się również założenie, 
że z uczestnictwa we mszy zwolnione są dzieci poniżej siódmego roku życia, chorzy oraz osoby starsze o ograniczonych możliwościach poruszania się. Analizując przeciętną strukturę demograficzną parafii, ustalono, że osoby zwolnione z udziału we mszy to $18 \%$ populacji, co oznacza, że zobowiązani stanowią $82 \%$ wszystkich wiernych. Obliczenia wykonano według wzoru:

$$
\mathrm{D}=\mathrm{O} / \mathrm{Z} \text { oraz } \mathrm{C}=\mathrm{K} / \mathrm{Z}
$$

gdzie:

D - dominicantes,

C-communicantes,

$\mathrm{O}$ - liczba obecnych na mszy św.,

$\mathrm{K}$ - liczba przystępujących do komunii św.,

Z - liczba zobowiązanych do uczestnictwa we mszy św.

Pomiary wskaźników dominicantes i communicantes, dokonywane przez instytucje kościelne, przedstawiają zróżnicowanie przestrzenne oraz czasowe zjawiska. Nie są jednak w stanie uchwycić zróżnicowania wynikającego z różnej tożsamości narodowej. Badania prowadzone przez autora tego artykułu miały za zadanie wyznaczenie wyżej wymienionych wskaźników niezależnie dla obu narodowości zamieszkujących ten sam teren, a następnie ich porównanie i przeanalizowanie. Za Litwinów uznano osoby przychodzące na msze w języku litewskim, za Polaków biorące udział w polskich mszach.

W tym celu autor przyjął następujący wzór na wskaźnik dominicantes dla danej narodowości:

$$
\mathrm{D}_{\mathrm{x}}=\mathrm{O}_{\mathrm{x}} / \mathrm{L}_{\mathrm{x}}
$$

odpowiednio: $\quad \mathrm{D}_{\mathrm{P}}=\mathrm{O}_{\mathrm{P}} / \mathrm{L}_{\mathrm{P}} \quad$ dla Polaków $\mathrm{D}_{\mathrm{L}}=\mathrm{O}_{\mathrm{L}} / \mathrm{L}_{\mathrm{L}} \quad$ dla Litwinów

gdzie:

D - dominicantes (odpowiednio dla Polaków i Litwinów),

O - liczba obecnych na mszy św. (odpowiednio polskiej i litewskiej),

L - liczba zobowiązanych do uczestnictwa we mszy św. wśród danej narodowości (odpowiednio Polaków i Litwinów).

Analogicznie wyliczono wskaźnik communicantes. 


\subsection{Ograniczenia w interpretacji wyników}

Posłużenie się powyższymi wskaźnikami wymaga jednak uprzedniego przyjęcia kilku założeń:

a) obie narodowości powinny być silnie przywiązane do swojego języka, w szczególności w zakresie używania go w kościele

W przypadku spełnienia tego kryterium członkowie każdej ze społeczności z zasady chodzą wyłącznie na mszę we własnym języku. Pozwala to utożsamić zmienną $\mathrm{O}$ ze zmienną $\mathrm{O}_{\mathrm{x}}$. W praktyce na Wileńszczyźnie korelacja między tożsamością narodową a preferowaną mszą jest niezwykle silna. Sytuacja, w której Polak brałby udział we mszy św. sprawowanej w języku litewskim lub Litwin we mszy w języku polskim (w założeniu, że w danej parafii są nabożeństwa sprawowane w obu językach), jest bardzo rzadka.

b) języki powinny istotnie różnić się

Język polski i litewski należą do zupełnie innych grup językowych. O ile na Białorusi istnieje spory odsetek wiernych, którzy nie mają preferencji co do języka polskiego lub białoruskiego, a w niektórych miejscach rosyjskiego (jedną z przyczyn, choć nie najważniejszą, tej sytuacji jest podobieństwo języków), o tyle na Litwie taka sytuacja praktycznie się nie zdarza.

c) osoby innych narodowości niż badane powinny stanowić znikomy odsetek społeczności katolickiej

Na Wileńszczyźnie warunek ten jest spełniony. Rosjanie z zasady należą do Cerkwi prawosławnej lub są niewierzący (ryc. 1), podobnie Ukraińcy, także Karaimi i Tatarzy, w dużej części należą do innych wspólnot religijnych. Wyjątkiem są Białorusini, stanowią jednak nieznaczny odsetek społeczności katolickiej w parafiach objętych badaniem.

d) wśród badanych narodowości znikomy odsetek powinny stanowić osoby innego wyznania. Pozwala to utożsamić liczbę ludności danej narodowości zamieszkującej obszar parafii z liczbą zobowiązanych dla tej narodowości. Obliczenia te wykonano według wzoru:

$$
\mathrm{Z}+\mathrm{W}=\mathrm{L}_{\mathrm{P}}+\mathrm{L}_{\mathrm{L}}
$$

gdzie:

W - Polacy i Litwini innego wyznania niż katolickie (tzn. niezobowiązani). Im mniejsze $\mathrm{W}$, tym założenie, że $\mathrm{Z}=\mathrm{L}_{\mathrm{P}}+\mathrm{L}_{\mathrm{L}}$ jest obarczone mniejszym błędem. 


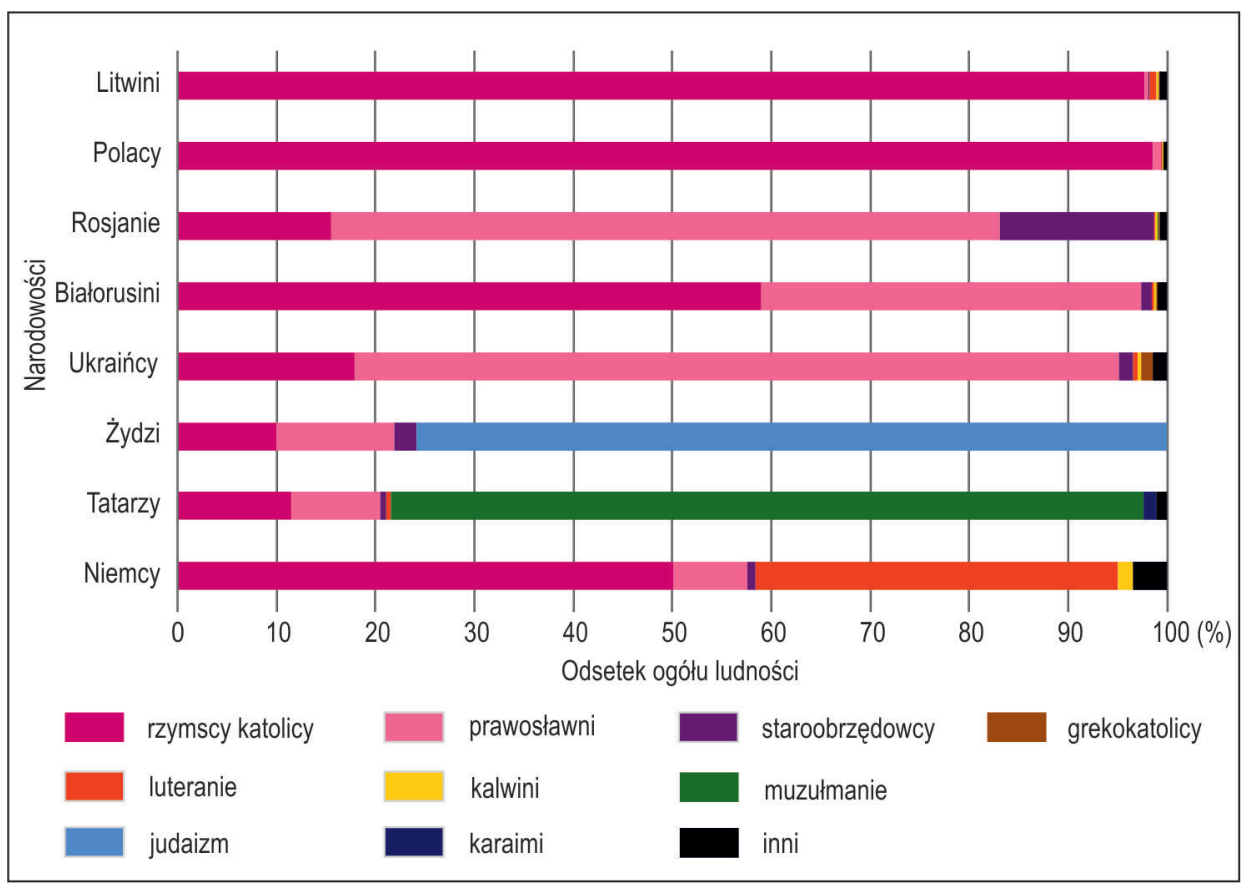

Ryc. 1. Struktura wyznaniowa najliczniejszych wspólnot narodowych na Litwie 
W przypadku archidiecezji wileńskiej również ten warunek jest spełniony, ponieważ Polacy i Litwini są najbardziej jednolitymi wyznaniowo grupami narodowymi na Litwie (ryc. 1). Przynależność do innych wyznań niż katolickie jest niezmiernie rzadka: w przypadku Polaków jedynie 1,2\% ogółu należy do innych wspólnot religijnych, natomiast wśród Litwinów 1,9\%.

\subsection{Dobór jednostek badawczych (parafii)}

Do przeprowadzenia pomiaru wytypowane mogły być tylko parafie, w których jest co najmniej jedna msza św. sprawowana w języku polskim i jedna w języku litewskim, tak aby wierni mieli swobodę wyboru nabożeństwa.

W archidiecezji wileńskiej warunek ten spełnia 30 parafii. Najwięcej znajduje się w dekanacie trockim i mejszagolskim (ryc. 2) oraz w okolicach Podgrodzia, czyli po zachodniej i północnej stronie Wilna. Ludność polska w tych parafiach jest autochtoniczna. W przypadku ludności litewskiej sytuacja jest zróżnicowana, część również jest autochtoniczna, natomiast część (wschodnia część dekanatu trockiego oraz większość mejszagolskiego) sprowadziła się tutaj po II wojnie światowej. Dobrze obrazuje to odsetek ludności litewskiej - najwyższy w miastach, dość duży w większych wsiach i zdecydowanie niższy w małych.

W 25 parafiach liturgia niedzielna sprawowana jest wyłącznie w języku litewskim. Dominują one w dekanacie orańskim oraz ignalińskim, czyli na północnym oraz południowym krańcu archidiecezji, zamieszkanym przez autochtoniczną ludność litewską. Charakterystyczne dla dekanatu ignalińskiego jest to, że jeden ksiądz obsługuje kilka bardzo małych, ale formalnie niezależnych parafii - dlatego ten dekanat wyróżnia się znacznie większą liczbą parafii (tab. 1). Parafii z niedzielnymi nabożeństwami wyłącznie w języku polskim jest 24. Dominują we wschodniej części dekanatu

Tab. 1. Liczba parafii w dekanatach archidiecezji wileńskiej w 2014 r.

\begin{tabular}{|l|c|}
\hline \multicolumn{1}{|c|}{ Dekanat } & Liczba parafii \\
\hline orański & 9 \\
\hline solecznicki & 12 \\
\hline trocki & 8 \\
\hline niemenczyński & 14 \\
\hline mejszagolski & 8 \\
\hline święciański & 10 \\
\hline ignaliński & 21 \\
\hline
\end{tabular}

Źródło: opracowanie własne na podstawie www.vilnius.lcn.lt, 20.03.2014 r. 
niemenczyńskiego oraz dekanacie solecznickim. W archidiecezji są również trzy małe parafie (Olany w dekanacie mejszagolskim, Norwiliszki w dekanacie solecznickim oraz Turmonty w dekanacie ignalińskim), gdzie odprawiana jest tylko jedna msza święta częściowo w obu językach.

\section{Wyniki obserwacji}

Wybór jednostek operacyjnych do przeprowadzenia badań ograniczał się zatem do 30 parafii (ryc. 2 - zaznaczone na żółto). Spośród nich wytypowano pięć placówek o zróżnicowanym składzie etnicznym (ryc. 3). Na terenie parafii Landwarów i Troki zdecydowaną większość stanowi ludność litewska, natomiast w parafii Rudziszki mieszka zbliżona liczba wiernych obu narodowości (tab. 2). W Podbrzeziu i Kowalczukach dominują Polacy.

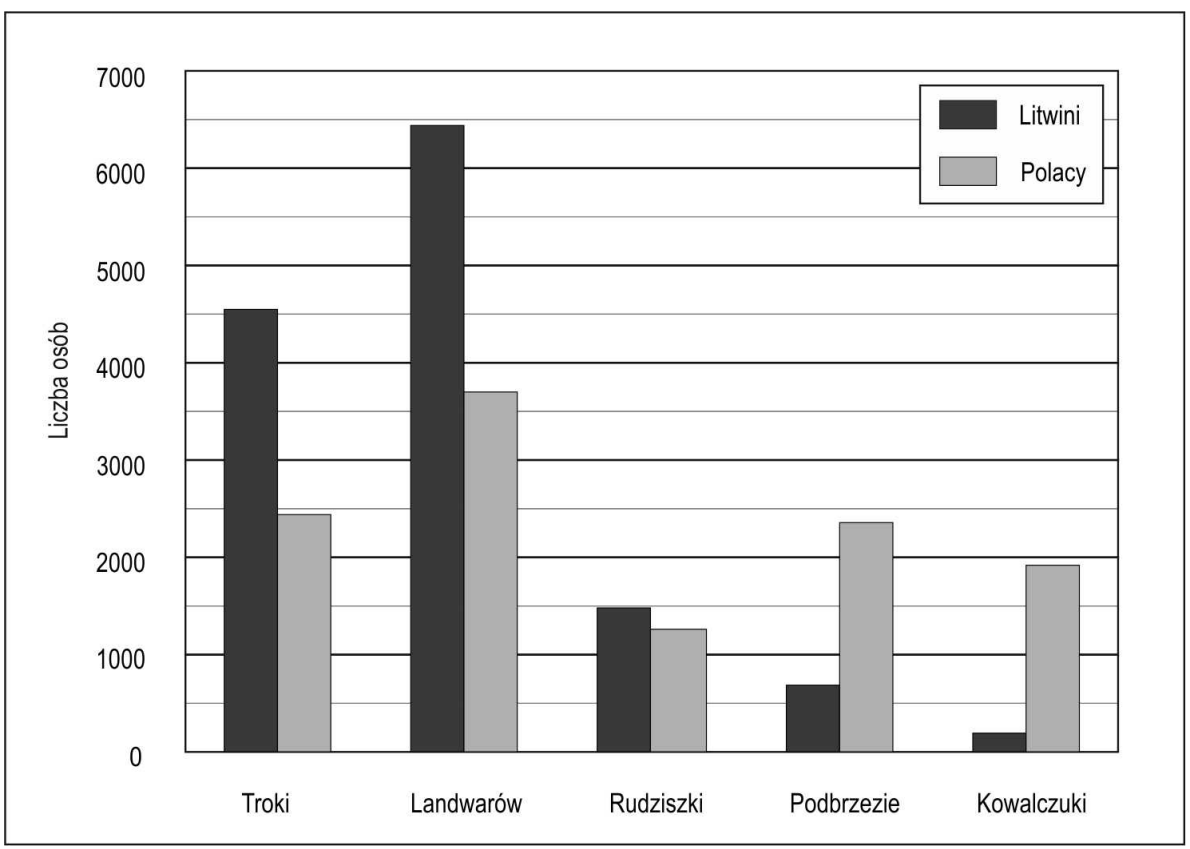

Ryc. 3. Liczebność społeczności polskiej i litewskiej na terytorium badanych parafii 


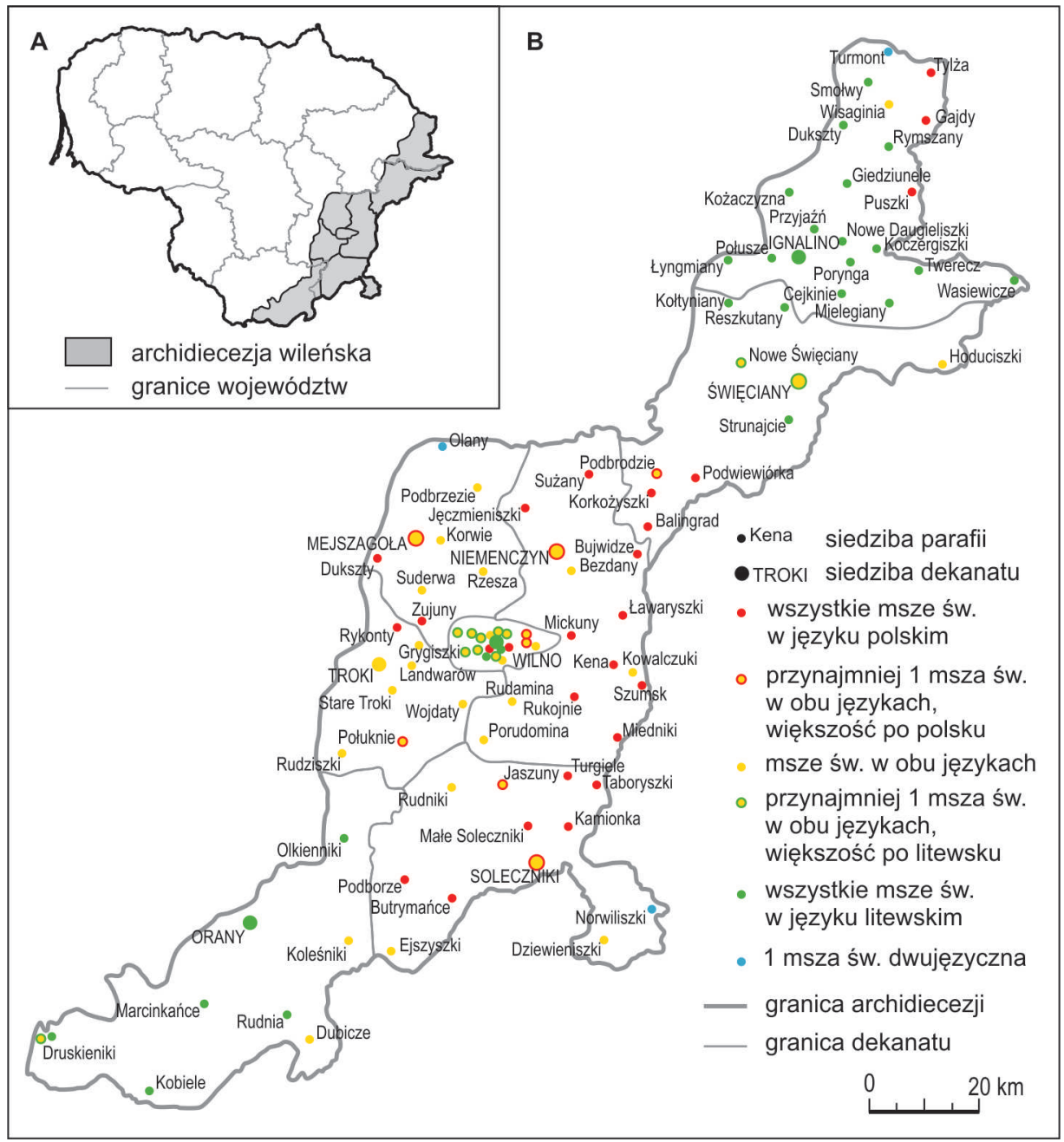

Ryc. 2. Msze święte niedzielne w archidiecezji wileńskiej w 2014 r. 
Tab. 2. Wskaźniki dominicantes oraz communicantes dla badanych parafii

\begin{tabular}{|c|c|c|c|}
\hline \multirow{2}{*}{ Parafia } & \multirow{2}{*}{ Ogółem } & \multicolumn{2}{|c|}{ w tym: } \\
\hline & & Litwini & Polacy \\
\hline \multicolumn{4}{|c|}{ Troki } \\
\hline liczba mieszkańców & 6988 & 4550 & 2438 \\
\hline liczba „zobowiązanych” & 5730 & 3731 & 1999 \\
\hline liczba osób na mszy & 300 & 180 & 120 \\
\hline liczba osób przystępujących do komunii & 184 & 100 & 84 \\
\hline dominicantes & $5,2 \%$ & $4,8 \%$ & $6,0 \%$ \\
\hline communicantes & $3,2 \%$ & $2,7 \%$ & $4,2 \%$ \\
\hline \multicolumn{4}{|c|}{ Landwarów } \\
\hline liczba mieszkańców & 10136 & 6439 & 3697 \\
\hline liczba „zobowiązanych” & 8312 & 5280 & 3032 \\
\hline liczba osób na mszy & 419 & 144 & 275 \\
\hline liczba osób przystępujących do komunii & 224 & 67 & 157 \\
\hline dominicantes & $5,0 \%$ & $2,7 \%$ & $9,1 \%$ \\
\hline communicantes & $2,7 \%$ & $1,3 \%$ & $5,2 \%$ \\
\hline \multicolumn{4}{|c|}{ Rudziszki } \\
\hline liczba mieszkańców & 2728 & 1481 & 1247 \\
\hline liczba „zobowiązanych” & 2237 & 1214 & 1023 \\
\hline liczba osób na mszy & 118 & 51 & 67 \\
\hline liczba osób przystępujących do komunii & 74 & 34 & 40 \\
\hline dominicantes & $5,3 \%$ & $4,2 \%$ & $6,6 \%$ \\
\hline communicantes & $3,3 \%$ & $2,8 \%$ & $3,9 \%$ \\
\hline \multicolumn{4}{|c|}{ Podbrzezie } \\
\hline liczba mieszkańców & 3040 & 685 & 2355 \\
\hline liczba „zobowiązanych” & 2493 & 562 & 1931 \\
\hline liczba osób na mszy & 276 & 70 & 206 \\
\hline liczba osób przystępujących do komunii & 154 & 25 & 129 \\
\hline dominicantes & $11,1 \%$ & $12,5 \%$ & $10,7 \%$ \\
\hline communicantes & $6,2 \%$ & $4,5 \%$ & $6,7 \%$ \\
\hline \multicolumn{4}{|c|}{ Kowalczuki } \\
\hline liczba mieszkańców & 2095 & 192 & 1903 \\
\hline liczba „zobowiązanych” & 1717 & 157 & 1560 \\
\hline liczba osób na mszy & 291 & 11 & 280 \\
\hline liczba osób przystępujących do komunii & 180 & 4 & 176 \\
\hline dominicantes & $16,9 \%$ & $6,9 \%$ & $18,0 \%$ \\
\hline communicantes & $10,4 \%$ & $2,5 \%$ & $11,3 \%$ \\
\hline
\end{tabular}

Źródło: obliczenia własne na podstawie własnych badań terenowych, dane ludnościowe obliczenia własne na podstawie www.stat.gov.lt. 
Zgodnie z metodologią badań liczbę zobowiązanych stanowi 82\% członków parafii - w przypadku wskaźnika uwzględniającego narodowość jest to zatem 82\% Polaków i 82\% Litwinów mieszkających w granicach parafii.

\section{Dyskusja i wnioski}

Obliczony wskaźnik dominicantes dla poszczególnych parafii jest mocno zróżnicowany. W przypadku trzech parafii waha się w przedziale od 5,0\% do 5,5\%, natomiast dla pozostałych dwóch wynosi odpowiednio 11,1\% i 16,9\% (tab. 2). Średni wynik dla wszystkich przebadanych parafii stanowi 6,9\%. Wskaźnik communicantes również jest zróżnicowany i mieści się w przedziale 2,7\% - 10,4\%, osiągając średnio 4,0\%.

Otrzymane wyniki pokazują zróżnicowanie wskaźników zaangażowania religijnego dla obu badanych społeczności narodowych. Średni wynik wskaźnika dominicantes dla wszystkich przebadanych parafii dla społeczności litewskiej wyniósł 4,2\%, natomiast dla społeczności polskiej 9,9\%. Interesująca jest analiza wyników dla poszczególnych parafii. W dwóch przypadkach wynik społeczności polskiej był aż trzykrotnie wyższy (w Kowalczukach o 11,1 punktu procentowego i Landwarowie o 6,4 p.p.), w kolejnych dwóch był wyższy o kilkadziesiąt procent (w Trokach o 1,2 p.p., tj. 25\% i Rudziszkach o 2,4 p.p, tj. 57\%). Wyjątkiem była jedynie parafia Podbrzezie, gdzie o 17\% wyższy wskaźnik (tj. 1,8 p.p.) osiągnęła społeczność litewska.

Średni wynik wskaźnika communicantes dla wszystkich pięciu parafii dla społeczności litewskiej wyniósł 2,1\%, natomiast dla społeczności polskiej 6,1\%. Oznacza to, że dokładnie połowa osób uczestniczących we mszach św. sprawowanych w języku litewskim przystępuje do komunii, podczas gdy wśród uczestników mszy sprawowanych w języku polskim jest to $62 \%$. We wszystkich parafiach wskaźnik ten był wyższy dla społeczności polskiej. W przypadku dwóch parafii (Kowalczuki, Landwarów) był aż czterokrotnie wyższy. Interesujący jest przypadek Podbrzezia, gdzie społeczność litewska mimo wyższego wskaźnika dominicantes ma niższy wskaźnik communicantes. Zatem do komunii przystępuje znacznie mniejszy odsetek uczestników mszy sprawowanych w języku litewskim niż w języku polskim. W przypadku liturgii litewskiej jest to 36\%, podczas gdy dla polskiej prawie 63\%.

Przeprowadzone badania miały zweryfikować czy istnieje zależność między narodowością a religijnością. Otrzymane wyniki (dwukrotnie wyższe dla 
społeczności polskiej w porównaniu ze społecznością litewską w przypadku wskaźnika dominicantes i trzykrotnie wyższe dla wskaźnika communicantes) wydają się potwierdzać tezę o zależności między tożsamością narodową a stopniem pobożności, weryfikowanym frekwencją podczas obowiązkowej niedzielnej liturgii. Jednak liczba jednostek operacyjnych poddanych badaniu była na tyle mała, że trudno na jej podstawie formułować wnioski bardziej ogólne, na temat całych społeczności zamieszkujących badany obszar.

\section{Literatura}

Babiński G., 1997, Pogranicze polsko-ukraińskie, Wyd. Nomos, Kraków.

Ciupak E., 1982, Religia i religijność, Wyd. Iskry, Warszawa.

Eberhardt P., 1998, Polska ludność kresowa, Wyd. PWN, Warszawa.

Vaitekūnienè V., 2013, Gyventojai pagal tautybę, gimtają kalba ir tikyba, Wyd. Lietuvos Statistikos Departamentas, Wilno.

Żelazny W., 2006, Etniczność - ład, konflikt, sprawiedliwość, Wyd. Poznańskie, Poznań.

\section{Źródła internetowe}

www 1: Instytut Statystyki Kościoła Katolickiego, http://www.iskk.pl/kosciolnaswiecie/63-dominicantes.html (25.09.2015).

www 2: Lietuvos Statistikos Departamentas, http://www.stat.gov.lt (02.10. 2015).

www 3: Strona internetowa archidiecezji wileńskiej, http://www.vilnius.lcn.lt

(02. 10.2015).

Maciej Trojnar, mgr

Instytut Geografii i Gospodarki Przestrzennej

Uniwersytet Jagielloński w Krakowie 
